\title{
Improving the provision of OTC medication information in community pharmacies in Poland
}

\author{
Anna Piecuch $^{1} \cdot$ Magdalena Makarewicz-Wujec $^{1} \cdot$ Małgorzata Kozłowska-Wojciechowska' $^{1}$
}

Received: 19 November 2015/Accepted: 11 November 2016/Published online: 30 November 2016

(c) The Author(s) 2016. This article is published with open access at Springerlink.com

\begin{abstract}
Background An informed or shared decisionmaking model is desirable to support the choice of overthe-counter (OTC) medications in pharmacies: it respects patient empowerment in self-medication. Such a model is achievable provided that pharmacists are a credible, competent information source open to patient needs. Objective To study the dependencies among selected factors that may influence the provision of OTC medication information. The study was conducted from the perspective of a community pharmacist. Method The study consisted of an auditorium survey with a self-administered questionnaire. We attempted to determine the relationships among three selected constructs: patient centredness (four items), competence (four items), and provision of OTC medication information (six items) as latent variables. We analysed hypothetical relationships among the observable variables and latent variables using structural equation modelling. Main outcome measure Selected factors that may influence the provision of OTC medication information. Results In all, 1496 pharmacists took part in the study. The model demonstrated adequate fit $\left(\chi^{2}=198.39, d f=64\right)$. The patient-centredness construct was demonstrated to have a strong direct positive impact on the provision of OTC medication information construct $(\beta=0.77, P<0.05)$. Provision of OTC medication information was also shown to have a strong direct effect on the competence variable ( $\beta=0.90, P<0.05$ ). Conclusion If a pharmacist is patient centred, there is a greater possibility that they will provide
\end{abstract}

Anna Piecuch

anna.piecuch@wum.edu.pl

1 Department of Clinical Pharmacy and Pharmaceutical Care, Faculty of Pharmacy, Medical University of Warsaw, ul. Banacha 1, 02-097 Warsaw, Poland information about OTC medicines; that may influence the pharmacist's feelings about their ability to cope with patient initiatives and enhance the pharmacist's selfperceived competence.

Keywords Community pharmacy $\cdot$ Medicine information Patient $\cdot$ Pharmacy services · Poland

\section{Impact of findings on practice}

- The patient-centred approach should be implemented and supported in pharmacy practice in Poland.

- Poland's pharmacists should develop their professional competencies for providing information on OTC medications.

- The Polish Pharmaceutical Chamber should support the provision of OTC medication information by issuing appropriate guidelines and advocating legal changes.

\section{Introduction}

An informed or shared decision-making model is desirable when choosing over-the-counter (OTC) medication in a pharmacy [1]: such a model respects patient empowerment in self-medication [2] and results from patient-centred care [3]. The concept of shared decision making is based on information exchange between a specialist (here, a pharmacist) and a patient; it also involves mutual expression of preferences and involvement of both the specialist and patient in the decision-making process [4]. With OTC medications, the final decision about medication choice rests with the patient, who is supported by the pharmacist 
in responsible self-medication [5]. To make informed decisions about medications, the patient needs an adequate range of clear information about both the risks and benefits of a given product $[2,6]$. The range of information and manner of its communication by the pharmacist should result in greater awareness and ability on the part of the patient to help them make informed choices [7]; such information should also ensure that the patient can obtain the greatest benefit by using a given medication [8] and avoid medication problems [7, 9].

To support a patient in meeting medication needs, a pharmacist needs to be credible and competent; this demands expertise and skilful information sharing with the patient (which is part of the shared decision-making model [4]) as well as respecting the patient's needs [10] (which results from patient-centred care [3]). Having trust in the pharmacist may be understood as, for example, perceiving them to be a reliable source of information. Demonstrating thorough interest in the patient may result in the patient openly expressing their needs and problems as well as asking pertinent questions [10].

The range and quality of information about dispensed medicines during an encounter may depend on strict laws and regulations [11]. In Poland, OTC medications are available at pharmacies [12], and they can be sold without prior interview with or assessment by the patient. OTC medications are also available at dispensaries [13] in rural areas that lack community pharmacies [14]. In addition, some OTC medications may be sold in other retail outlets [15], e.g. general stores. Legal requirements oblige people who dispense medications in Polish pharmacies to provide, if necessary, patients with information about given medications-both prescription and OTC medications. Such requirements particularly apply to the methods of administration, storage conditions, pharmacological effects, and possible interactions with other medications [16].

In practice, however, fulfilling this obligation markedly differs among individual pharmacies; this is due to generalized, ambiguous legal requirements that are particularly questionable concerning the interpretation of the "if necessary" wording. The kind of information supplied is commonly limited to instructing the patient [17]. Interactions between pharmacists and patients in Poland tend to brief and mainly product oriented, not patient centred. Depending on the type of transaction, the content of communication between a pharmacist and patient, including the range of information provided by the pharmacist to the patient, is determined by both participants in the interaction [18]. If the pharmacist waits for the patient to make the initiative and start asking questions, the pharmacist may fail and the patient will not obtain important information [19]. The most important information about a medicinal product is provided in the package leaflet
[20, 21]. However, such written information should not replace the communication between a pharmacist and patient but supplement it [22]. Verbal information provided to patients should strictly correspond to their needs [23]. It is known that an adequate interview and assessment are necessary to provide appropriate advice or medical referral; however, there are no commonly accepted rules in Poland concerning the patient interview at a pharmacy [24].

A pharmacist in Poland can influence the choice and use of OTC medications by a patient. The focus of the present study is self-medication.

\section{Aim of the study}

The objective of this study was to explore the interplay between selected constructs (pharmacist's patient-centredness and competence) that may influence the provision of medication information by pharmacists. The study was conducted from the perspective of a community pharmacist.

\section{Ethics approval}

Ethics approval was not required for this study. According to Polish regulations, non-interventional studies do not require ethical approval [25].

\section{Method}

\section{Sample}

We distributed a self-administered questionnaire among 4537 pharmacists, between 3 March and 24 November 2012. No incentives were offered to participants.

The sample covered pharmacists who took part in an ongoing education course in geriatric pharmaceutical care, delivered by the Centre of Postgraduate Training of the Medical University of Warsaw, Faculty of Pharmacy. The course was directed at pharmacists working at pharmacies, dispensaries, and pharmaceutical wholesalers. The course was a 1-day symposium. One of the lectures addressed the potential for collaboration between a pharmacy and a patient as well as selected issues concerning OTC medicines and self-medication. The course was free of charge and open to all eligible pharmacists who had made a prior registration. The course was delivered according to the same curriculum and by the same lecturers in 16 cities across Poland. Continuing education of pharmacists is compulsory in Poland, and this particular symposium was 
very well attended by community pharmacists. The course was not held in the area covered by four regional pharmaceutical chambers: Środkowopomorska, Kaliska, Beskidzka, and Częstochowska regional pharmaceutical chambers, which account for $20 \%$ of all such chambers in the country.

The inclusion criteria for study participants were as follows: licensed pharmacists working at community pharmacies; licensed pharmacists working at dispensaries. The exclusion criteria were as follows: licensed pharmacists working at hospital pharmacies; licensed pharmacists working at pharmaceutical wholesalers; non-pharmacists, including owners of pharmacies who did not hold a master's degree in pharmacy, students of pharmacy, and pharmacy technicians; and incomplete data (missing responses to over three items in the 14-item scale).

\section{Survey}

The study questionnaire consisted of three parts. The first part included questions about the relationship between pharmacists and physician and will be discussed in more detail in a subsequent report. The second part addressed pharmacist-patient communication. The third part covered socio-demographic questions.

With the survey, we attempted to explore the interplay among three selected constructs. Discussions within the research team resulted in the development of the initial constructs and indicators. The indicators were then further developed based on in-depth interviews with a convenience sample of eight pharmacists. One of the researchers took notes of the pharmacists' opinions. The pharmacists talked about the kind of information they provided and, in their opinion, should be provided to patients when selling OTC medications. The pharmacists also spoke about when patients could ask them for help, how they demonstrated their interest in the patient's welfare, and how they dealt with their own credibility. The patient-centredness construct (PAT) consisted of four items (with one reversecoded item); the competence construct (COM) was also made up of four items; and the provision of medication information construct (INF) was based on six items (with one reverse-coded item). We applied a five-point Likert scale in the survey, the total score being the sum of all item scores. A respondent had to answer at least $80 \%$ of the items. Missing values for one to three items were replaced with the mean score calculated from items completed by the respondent.

An additional question addressed general self-assessment concerning relations between the pharmacist and patient (using a five-point scale from "very good" to "very bad").
Patient-centredness. In this study, PAT was considered in terms of taking care of the patient's needs as well as acting with good intention and in the patient's best interest.

Competence. COM was defined as the pharmacist's expertise in OTC medications and their openness to medication needs and patient questions.

Provision of medication information. INF was understood as providing patients with basic information necessary to ensure safety and efficacy with self-medication (i.e. method of administration, storage conditions, contraindications, possible side effects, and interactions).

\section{Analysis}

We used Statistica 10 software for statistical analysis. Structural equation modelling using LISREL 8.80 was performed by an external service provider.

\section{Results}

Of 1722 completed questionnaires (response rate, 38.0\%), 226 were rejected as incomplete or failed to comply with the inclusion criteria. Thus, 1496 responses qualified for further analysis, accounting for $33.0 \%$ of the originally distributed questionnaires. A summary of the socio-demographic characteristics of participants is provided in Table 1. With reference to data from Poland's Central Statistical Office [26], the proportion of female respondents was slightly higher than in the general population of pharmacists ( 88 vs. $84 \%$ ). We found no statistically significant differentiation with regard to socio-demographic factors $(P<0.05)$.

The median (interquartile range) numbers and proportions of responses to the study items are listed in Table 2 . Estimation of the parameters and the fit of the structural equation model indicated good fit of the data to the proposed model. The Chi square test to test the absence of a perfect data-model fit hypothesis was statistically significant: $\chi(64)=198.39, P<0.001)$. The model actually fitted the data very well, as evidenced in the root mean square error of approximation (RMSEA) value of 0.038 . It was evident that the latent variables introduced into the model were strongly positively intercorrelated. All the relationships between the observable and latent variables were statistically significant; if they were eliminated, the fit of the model would be negatively affected.

We calculated skewness and kurtosis for the observable variables. Since the variants did not meet the consistency condition with a normal distribution, we used a weighted least-squares estimator. Spearman's rank correlation matrix 
Table 1 Sociodemographic characteristics of the study sample

\begin{tabular}{|c|c|}
\hline Independent variables & $\mathrm{n}=1496(\%)$ \\
\hline Age & $40 \pm 11$ years \\
\hline \multicolumn{2}{|l|}{ Sex } \\
\hline Female & $1312(87.7)$ \\
\hline Male & $184(12.3)$ \\
\hline \multicolumn{2}{|l|}{ Years in practice } \\
\hline$\leq 5$ & $445(30.1)$ \\
\hline $6-10$ & $201(13.6)$ \\
\hline $11-15$ & $202(13.6)$ \\
\hline $16-20$ & $219(14.8)$ \\
\hline$>20$ & $413(27.9)$ \\
\hline \multicolumn{2}{|l|}{ Job position ${ }^{\mathrm{a}}$} \\
\hline Pharmacist (with a Masters degree in pharmacy) & $1496(100.0)$ \\
\hline Pharmacy manager & $630(42.1)$ \\
\hline Pharmacy owner & $156(10.4)$ \\
\hline Other job position & $2(<0.1)$ \\
\hline \multicolumn{2}{|l|}{ Pharmacy setting } \\
\hline Rural area & $115(7.7)$ \\
\hline Urban area of up to 20,000 inhabitants & $279(18.6)$ \\
\hline Urban area of $20,000-100,000$ inhabitants & $365(24.4)$ \\
\hline Urban area of $100,000-500000$ inhabitants & $291(19.5)$ \\
\hline Urban area of over 500,000 inhabitants & $431(28.8)$ \\
\hline No response & $15(1.0)$ \\
\hline \multicolumn{2}{|l|}{ Pharmacy } \\
\hline Independent pharmacy & $913(61.0)$ \\
\hline Chain pharmacy & $500(33.4)$ \\
\hline Other type of pharmacy & $83(5.5)$ \\
\hline \multicolumn{2}{|l|}{ Self-perceived pharmacist-patient relationships } \\
\hline Very good & $486(32.5)$ \\
\hline Good & $963(64.4)$ \\
\hline Neither good nor bad & $44(2.9)$ \\
\hline $\mathrm{Bad}$ & $3(0.2)$ \\
\hline Very bad & $0(<0.1)$ \\
\hline
\end{tabular}

a Answers do not sum up to $100 \%$ as multiple answers were possible

analysis revealed no collinearity among the analysed variables. All the correlations were statistically significant $(P<0.05)$.

The close-fit hypothesis was confirmed and accepted for the designed model [27]: RMSEA $=0.038$ was within the range of $(0.0 ; 0.5)$ for good-fit acceptance; the $90 \%$ confidence interval for the RMSEA population value $(0.032$; $0.044)$ was within the range of $(0.0 ; 0.5)$ for good-fit acceptance; and the $P$ value for the close-fit hypothesis (RMSEA $<0.05)$ equalled 1.

In the structural submodel, PAT was not a dependent variable. PAT had a strong direct positive impact on INF ( $\beta=0.77, P<0.05)$. PAT was also shown to have a strong direct effect on COM $(\beta=0.90, P<0.05)$, which means that PAT had an indirect impact on COM by means of INF (Fig. 1). Table 3 presents the results of confirmative factor analysis of the model.

\section{Discussion}

The patient-centred pharmacist can facilitate self-medication by providing information about OTC medications, dealing with patients' questions and concerns, and being open to patients' needs [28]. Many factors can influence the provision of information to patients at a pharmacy: whether any information is provided, the kind of information, its range, and its manner of presentation [29]. The provision of information depends on the pharmacist but also on the patients themselves [30], their needs related to the type of medication being dispensed, their health problems [31], and various external factors. With the final item, the following factors may be of importance: legal conditions and applicable guidelines [17]; and the system or organization of pharmacy activities [32]. In this paper, we examined only two selected constructs that may have an effect on the provision of information related to OTC medication. Owing to differences in the factors that can influence the provision of information to patients, our findings may not apply to other countries.

The analysis of the model showed that pharmacists who consider the position of the patient are more involved in providing OTC medication information; this in turn helps consolidate the pharmacist's self-perceived competence. In Poland, patients generally base their OTC drug choices on past experience; however, the possibility of consultation with a pharmacist is important for those who select a pharmacy when making an OTC purchase [33]. Previous studies on patient preferences in Poland have demonstrated that a pharmacy's location as well as the price and availability of drugs are considered more important than the possibility of consultation with a pharmacist [34]; around $50 \%$ of Poles use OTC medication for the first time without consulting a physician or pharmacist [35]. These results can be accounted for by the passive behaviour of pharmacists [36], the limited perceived reliability of pharmacist advice regarding medications, and the lack of confidentiality in a pharmacy setting $[34,36,37]$. In the present study, the overall score of PAT was reduced by pharmacists who responded that they would intentionally recommend a drug that would bring them a higher profit; this indicates that the social fear of mercantilism among pharmacies is not entirely unfounded. However, the character of the pharmacist plays a primary role as to whether they are regarded as an ordinary salesman or a trustworthy consultant [38]. 


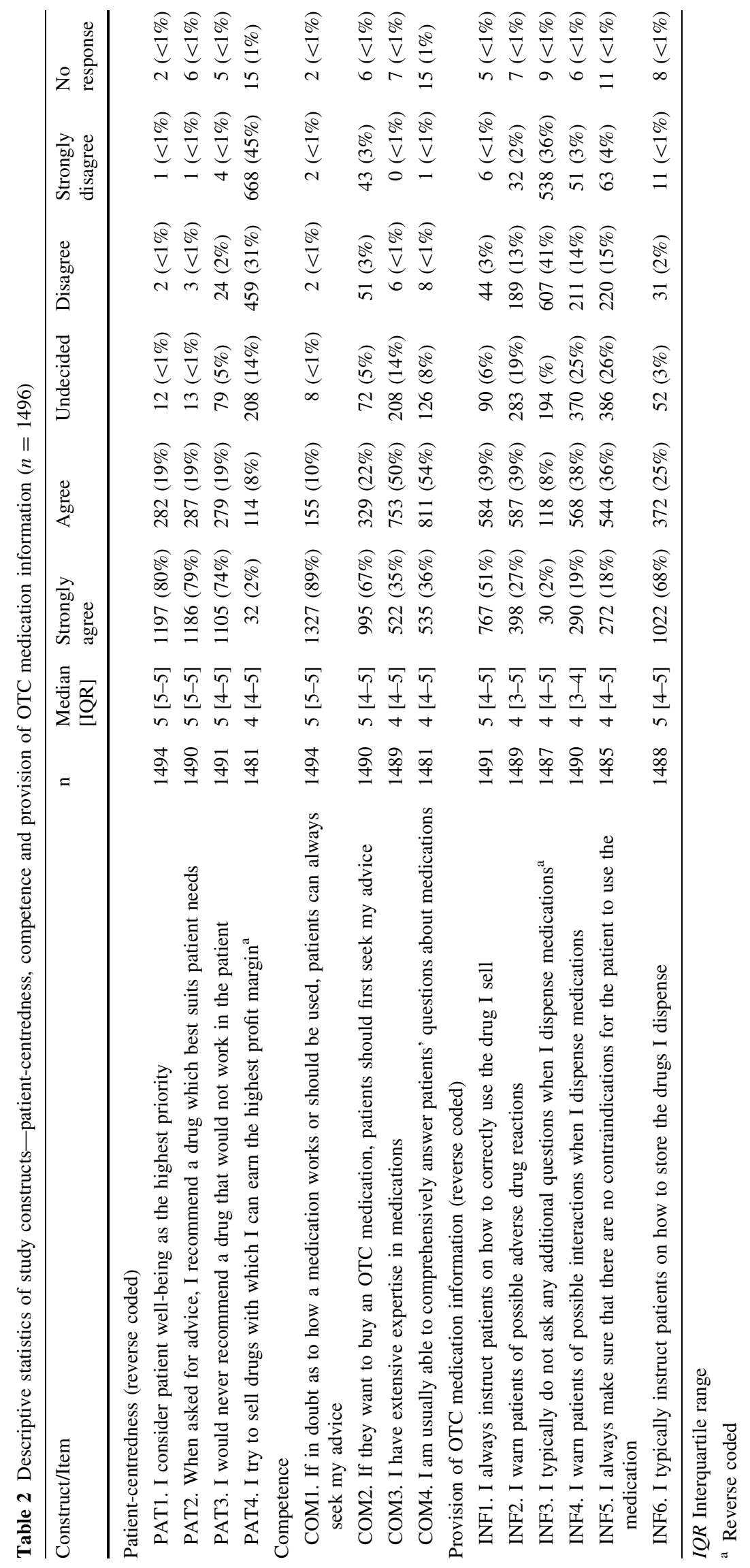


Fig. 1 Structural equation model showing relationships among the study constructs: patient centredness, competence, and provision of OTC medication information. $\chi^{2}=198.39, d f=64$,

$P<0.001$, root mean square of approximation $=0.038 \mathrm{COM}-$ competence INF-provision of OTC medication information PAT—patient centredness

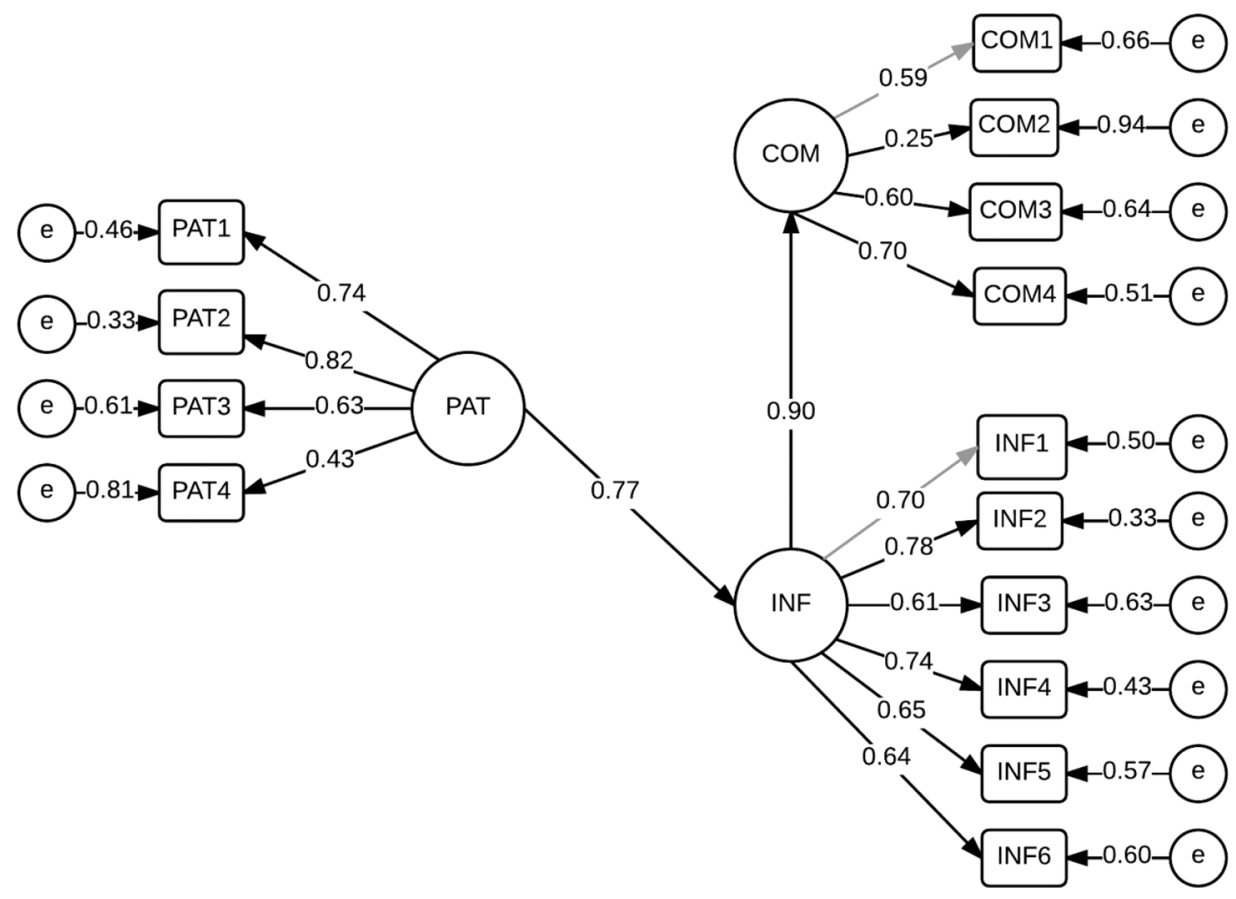

\begin{tabular}{lllll}
\hline Variable & SRW & URW & SE URW & $\begin{array}{l}\text { Cronbach } \\
\text { coefficient alpha }\end{array}$ \\
\hline
\end{tabular}

\begin{tabular}{llll}
\multicolumn{2}{l}{ Patient-centredness } \\
PAT1 & 0.74 & 2.22 & 0.11 \\
PAT2 & 0.82 & 2.46 & 0.11 \\
PAT3 & 0.63 & 0.83 & 0.04 \\
PAT4 & 0.43 & 0.58 & 0.04 \\
Competence & & & \\
COM1 & 0.59 & 4.65 & 0 \\
COM2 & 0.25 & 0.71 & 0.10 \\
COM3 & 0.60 & 0.37 & 0.03 \\
COM4 & 0.70 & 1.07 & 0.08
\end{tabular}

Provision of OTC medication information

$\begin{array}{llllll}\text { INF1 } & 0.70 & 0.89 & 0 & 0.78 & \\ \text { INF2 } & 0.78 & 0.80 & 0.03 & \\ \text { INF3 } & 0.61 & 0.81 & 0.04 & \\ \text { INF4 } & 0.74 & 0.83 & 0.03 & \\ \text { INF5 } & 0.65 & 0.76 & 0.03 & \\ \text { INF6 } & 0.64 & 1.19 & 0.05 & \end{array}$

$S R C$ Standardized regression coefficient, $U R W$ unstandardized regression weight, $S E$ standard error, $A V E$ average variance extracted

The pharmacists rated their competence and ethical conduct relatively highly. However, the responses of some pharmacists suggest that they may not provide comprehensive information to patients who buy OTC medications. The results of this study would appear to be consistent with those of investigations that have indicated that pharmacists in Poland do not always provide adequate, complete information to patients, especially when unsolicited
$[36,37]$. This may be explained by the fact that pharmacists simply lack the necessary practical skills and selfassurance. Another explanation is that COM was affected by lower ratings of self-perceived expertise in drugs and the ability to respond to patient questions. A further possible issue is that owing to legal requirements, pharmacists were not sufficiently motivated to properly support patient self-medication. 


\section{Limitations}

This study consisted of an auditorium survey with a selfadministered questionnaire, which had some inherent limitations [39]. The questionnaire was self-administered, but the respondents were able to see and even communicate with one another.

Measurement error was another possible limitation. The main probable cause was the data collection method, in which respondents self-reported their beliefs and behaviours. The study results could have been exposed to an error attributed to social expectations. Respondents may have been compelled to respond in a socially desirable manner rather than truthfully. With a relatively low response rate, error attributed to non-responses cannot be excluded. Moreover, it should be noted that the study covered a period of 9 months; during that time, some factors affecting the studied relationships could have changed considerably.

The pharmacist perspective was adopted in this study. Future research should also compare how patients respond to the same questions.

\section{Conclusion}

If a pharmacist is patient centred and considers the patient's welfare, there is a greater possibility that they will provide information about OTC medicines; that may influence the pharmacist's feeling about their ability to cope with patients' initiatives and enhance the pharmacist's self-perceived competence.

Funding This study was conducted as part of a research project implemented in 2012-14 under grant no. FW25A/PM31D/12 at the Faculty of Pharmacy of the Medical University of Warsaw.

Conflicts of interest The authors declare no conflicts of interest.

Open Access This article is distributed under the terms of the Creative Commons Attribution 4.0 International License (http://crea tivecommons.org/licenses/by/4.0/), which permits unrestricted use, distribution, and reproduction in any medium, provided you give appropriate credit to the original author(s) and the source, provide a link to the Creative Commons license, and indicate if changes were made.

\section{References}

1. Wirtz V, Cribb A, Barber N. Patient-doctor decision-making about treatment within the consultation-a critical analysis of models. Soc Sci Med. 2006;62(1):116-24.
2. Aslani P. Patient empowerment and informed decision-making. Int J Pharm Pract. 2013;21(6):347-8.

3. Mead N, Bower P. Patient-centredness: a conceptual framework and review of the empirical literature. Soc Sci Med. 2000;51(7):1087-110.

4. Murray E, Charles C, Gafni A, Shared decision-making in primary care: tailoring the Charles, et al. model to fit the context of general practice. Patient Educ Couns. 2006;62(2):205-11.

5. WHO. The Role of the Pharmacist in Self-Care and Self-Medication. Report of the 4th WHO Consultative Group on the Role of the Pharmacist. The Hague, The Netherlands: World Health Organization, 1998 (cited: 23 Feb 2016). http://apps.who.int/ medicinedocs/en/d/Jwhozip32e/.

6. Gaissmaier W, Gigerenzer G. Statistical illiteracy undermines informed shared decision making. Z Evid Fortbild Qual Gesundhwes. 2008;102(7):411-3.

7. Ryan R, Santesso N, Lowe D, Hill S, Grimshaw J, Prictor M, Kaufman C, Cowie G, Taylor M. Interventions to improve safe and effective medicines use by consumers: an overview of systematic reviews. Cochrane Database Syst Rev. 2014. doi:10. 1002/14651858.CD007768.pub3.

8. Joint FIP/WHO guidelines on good pharmacy practice: standards for quality of pharmacy services. WHO Technical Report Series, No. 961, 2011. Geneva: World Health Organization; 2011.

9. Pharmaceutical Care Network Europe. Classification for Drug related problems. V6.2. (revised: January 2010, cited: 22 Feb 2016) [Internet]. http://www.pcne.org/upload/files/11_PCNE_ classification_V6-2.pdf.

10. Berger BA. Building an effective therapeutic alliance: competence, trustworthiness, and caring. Am J Hosp Pharm. 1993;50(11):2399-403.

11. Kimberlin CL, Jamison AN, Linden S, Winterstein AG. Patient counseling practices in U.S. pharmacies: effects of having pharmacists hand the medication to the patient and state regulations on pharmacist counseling. J Am Pharm Assoc (2003). 2011;51(4):527-34.

12. Pharmaceutical Law Act of 6 September 2001, Journal of Laws. 2008; No 45, item 271, art. 96 par. 1.

13. Pharmaceutical Law Act of 6 September 2001, Journal of Laws. 2008; No 45, item 271, art. 70 par. 1.

14. Pharmaceutical Law Act of 6 September 2001, Journal of Laws. 2008; No 45, item 271, art. 70 par. 3.

15. Pharmaceutical Law Act of 6 September 2001, Journal of Laws. 2008; No 45, item 271 , art. 71 par. 1 .

16. Regulation of the Minister for Health of 18 October 2002 on selling medicinal products and medical devices in pharmacies, Journal of Laws. 2002; No. 183, item 1531, art. 2 par. 1 point 3.

17. Pilnick A. „Patient counseling” by pharmacists: Advice, information, or instruction? Sociol Quart. 1999;40:613-22.

18. Shah B, Chewning B. Conceptualizing and measuring pharmacist-patient communication: a review of published studies. Res Social Adm Pharm. 2006;2(2):153-85.

19. Krueger JL, Hermansen-Kobulnicky CJ. Patient perspective of medication information desired and barriers to asking pharmacists questions. J Am Pharm Assoc. 2011;51(4):510-9.

20. Regulation of the Minister for Health of 20 February 2009 on the requirements for medicinal product labelling and package leaflet content, Journal of Laws. 2009; No 39, item 321, as amended.

21. Directive 2001/83/EC of the European Parliament and of the Council of 6 November 2001 on the Community code relating to medicinal products for human use (Consolidated version: 2012 Nov 16): 2001. OJ L 311, p. 67.

22. Nathan JP, Zerilli T, Cicero LA, Rosenberg JM. Patients' use and perception of medication information leaflets. Ann Pharmacother. 2007;41(5):777-82. 
23. Duggan C, Bates I. Medicine information needs of patients: the relationships between information needs, diagnosis and disease. Qual Saf Health Care. 2008;17(2):85-9.

24. Schneider CR, Everett AW, Geelhoed E, Kendall PA, Murray K, Garnett P, Salama M, Clifford RM. Provision of primary care to patients with chronic cough in the community pharmacy setting. Ann Pharmacother. 2011;45(3):402-8.

25. Pharmaceutical Law Act of 6 September 2001, Journal of Laws. 2008; No. 45, item 271, art. 37al.

26. Central Statistical Office. Zdrowie i ochrona zdrowia w $2013 \mathrm{r}$. [Health and Health Care in 2013]. Warszawa: GUS; 2014. http:// stat.gov.pl/obszary-tematyczne/zdrowie/zdrowie/zdrowie-iochrona-zdrowia-w-2013-r-,1,4.html. Accessed on 31 March 2016). Polish.

27. Konarski R. Modele równań strukturalnych. Teoria i praktyka. Modele równań strukturalnych. Teoria i praktyka. [Structural Equation Modelling. Theory and Practice]. Warszawa: Wydawnictwo Naukowe PWN; 2010 (Polish).

28. Rutter P. Role of community pharmacists in patients' self-care and self-medication. Integr Pharm Res Pract. 2015;4:57-65.

29. Sabater-Galindo M, Fernandez-Llimos F, Sabater-Hernández D, Martínez-Martínez F, Benrimoj SI. Healthcare professionalpatient relationships: systematic review of theoretical models from a community pharmacy perspective. Patient Educ Couns. 2016;99(3):339-47.

30. Kaae S, Traulsen JM, Nørgaard LS. Challenges to counseling customers at the pharmacy counter-Why do they exist? Res Social Adm Pharm. 2012;8(3):253-7.

31. Duggan C, Bates I. Medicine information needs of patients: the relationships between information needs, diagnosis and disease. Qual Saf Health Care. 2008;17(2):85-9.

32. Urbonas G, Kubiliene L, Kubilius R, Urboniene A. Assessing the effects of pharmacists' perceived organizational support, organizational commitment and turnover intention on provision of medication information at community pharmacies in Lithuania: a structural equation modeling approach. BMC Health Serv Res. 2015; $15: 82$.

33. Federacja Konsumentów. Leki bez recepty: Raport z badania. [Over-the-counter medications: Report from the study] [Internet]. Warszawa, 2015. http://www.federacja-konsumentow.org.pl/ s, 1288,leki-bez-recepty-zwyczaje-i-preferencje-konsumentowmaterialy.html. Accessed on 01 April 2016. Polish.

34. Piecuch A, Kozłowska-Wojciechowska M. Self-medication in Poland: the pharmacist's advisory role in Warsaw. Int $\mathrm{J}$ Clin Pharm. 2013;35:225-9.

35. Roguska B, Feliksiak M. Stosowanie leków dostępnych bez recepty. [The use of non-prescription medicines] [Internet]. Warszawa: CBOS; 2010. Document no. BS/143/2010. http:// badanie.cbos.pl/details.asp?q=a1\&id=4382. Accessed on 06 April 2016. Polish.

36. Bułaś L, Skowron A, Olczyk P, Jurczyk A, Ulz Z. Ocena doradztwa farmaceutycznego w samoleczeniu w wybranych aptekach województwa śląskiego [Evaluation of self treatment pharmaceutical consulting in selected pharmacies in Silesia province]. Farm Pol. 2011;67(2):73-7 (Polish).

37. Drozd M, Kijewska A, Jaremek-Kudła J, Skowron A. Ocena porady farmaceuty $\mathrm{w}$ procesie samoleczenia [The estimate of pharmaceutical advice in self-medication]. Farm Pol. 2011;67(10):650-5 (Polish).

38. Szeinbach SL. Images of pharmacists and pharmacies. In: Smith MC, Wertheimer AI, editors. Social and behavioral aspects of pharmaceutical care. Milton Park: Taylor \& Francis; 1996. p. 85-98.

39. Żmijewska-Jędrzejczyk T, Dyjas-Pokorska A. Ankiety audytoryjne. [Self-administered questionnaires]. In: Fieldwork jest sztuką. Jak dobrać respondenta, skłonić do udziału w wywiadzie, rzetelnie i sprawnie zrealizować badanie. [Fieldwork is an art. How to select a respondent, convince respondents to take part in the interview, and reliably and effectively conduct the study]. Warszawa: IFIS; 2005. p. 299-316 (Polish). 